\title{
Deepwater Spawning of Fall Chinook Salmon (Oncorhynchus tshawytscha) near Ives and Pierce Island of the Columbia River
}

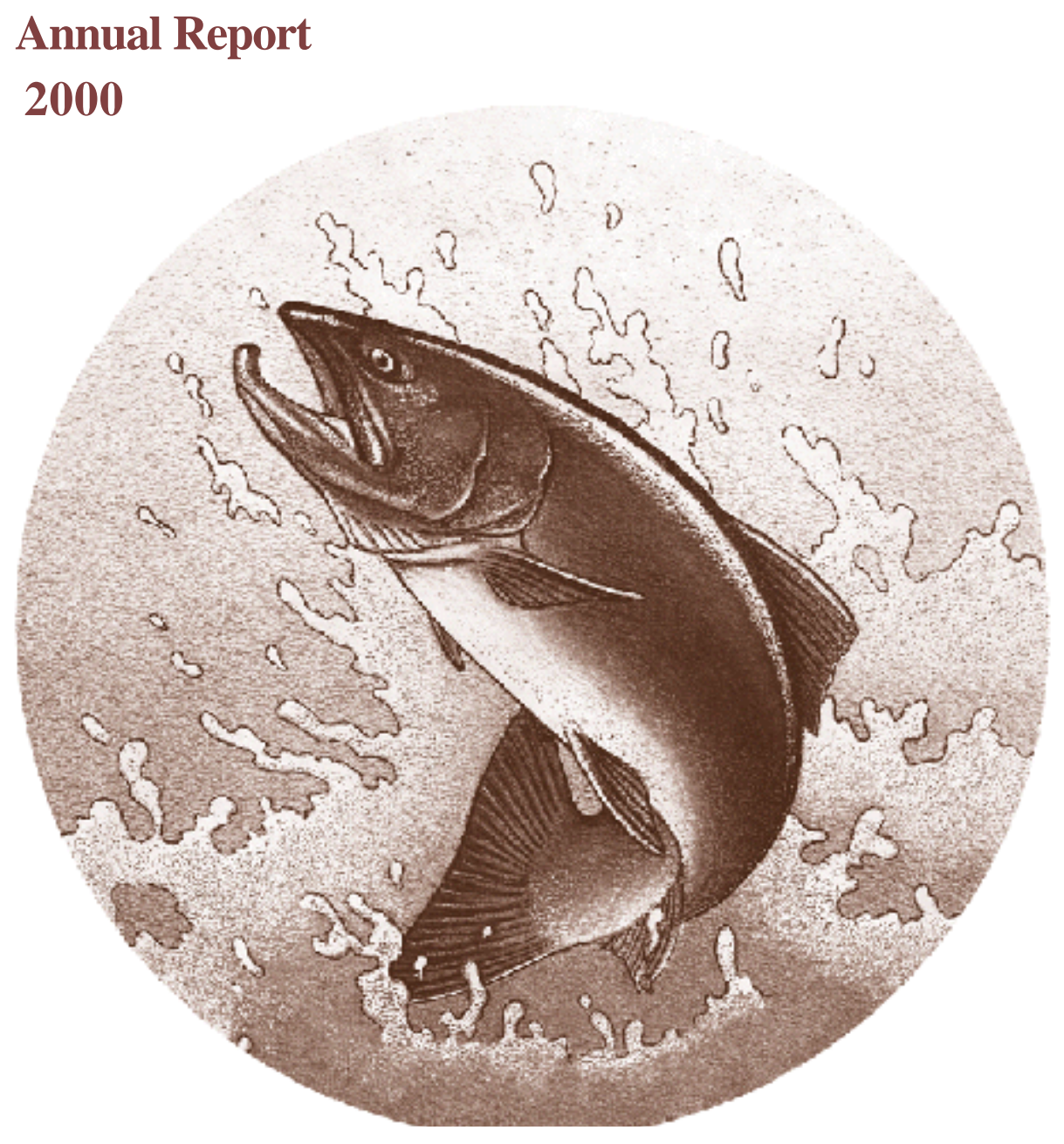

DOE/BP-00000652-6

October 2001 
This Document should be cited as follows:

Mueller, Robert, "Deepwater Spawning of Fall Chinook Salmon (Oncorhynchus

tshawytscha) near Ives and Pierce Island of the Columbia River", Project No. 1999-

00304, 27 electronic pages, (BPA Report DOE/BP-00000652-6)

\author{
Bonneville Power Administration \\ P.O. Box 3621 \\ Portland, Oregon 97208
}

This report was funded by the Bonneville Power Administration (BPA), U.S. Department of Energy, as part of BPA's program to protect, mitigate, and enhance fish and wildlife affected by the development and operation of hydroelectric facilities on the Columbia River and its tributaries. The views in this report are the author's and do not necessarily represent the views of BPA. 


\title{
Deepwater Spawning of Fall Chinook Salmon (Oncorhynchus tshawytscha) Near Ives and Pierce Island of the Columbia River, 2000
}

\author{
Prepared by: \\ Robert P. Mueller \\ Pacific Northwest National Laboratory ${ }^{1}$ \\ Richland, Washington 99352 \\ Prepared for: \\ U.S. Department of Energy \\ Bonneville Power Administration \\ Environment Fish and Wildlife \\ P.O. Box 3621 \\ Portland, Oregon 97208-3621 \\ BPA Project Number 199900301 \\ Contract Number 00000652
}

October 2001

${ }^{1}$ Pacific Northwest National Laboratory is operated for the U.S. Department of Energy by the Battelle Memorial Institute under contract DE-AC06-76RL01830. 


\section{Executive Summary}

Pacific Northwest National Laboratory (PNNL) initiated studies to identify potential fall chinook (Oncorhynchus tshawytscha) spawning habitat and assess that extent of spawning in deep water $(>2 \mathrm{~m}$ ) downstream of Bonneville Dam in the fall of 1999 and continued in the fall of 2000. This information was needed to provide estimates of the adult spawning population occurring in the area and assess any impacts of water flows on the spawning populations. Specific study objectives were to 1) determine if fall chinook salmon spawned downstream of Bonneville Dam near the Ives/Pierce island complex, 2) document the distribution and abundance of redds, and 3) obtain detailed information on habitat characteristics.

Geographic Information System (GIS) technology was used to create maps of potential spawning habitat (primary search areas) near the section of Columbia River where fall chinook salmon have been observed by visual observation. A boat-deployed underwater video system was then used to survey for salmon redds in primary search area and in other areas identified as potential spawning sites. The camera's position was tracked using a Global Positioning System (GPS) linked to a field computer equipped with GPS visualization software. Some individual redd locations were marked for later verification. GIS maps were produced of redd locations and to conduct spatial analyses of key habitat variables. Water quality, current velocity profiles, and substrate were also characterized as part of the spawning habitat studies.

Fall chinook salmon redds occurring in excess of $2 \mathrm{~m}$ were found to occur in a fairly confined area located downstream of Ives Island and adjacent to Pierce Island in 1999 and 2000. Small redd clusters of redds were also were found within the Hamilton Slough. A total of 151 fall chinook redds were found during 2000. Similar surveys conducted in 1999 by PNNL documented about 107 redds in this area. Fall chinook salmon redds occurred in depths from 2.2$6.2 \mathrm{~m}$ in water depth and comprised an area of $\sim 6.28$ ha. Fall chinook salmon preferred substrate sizes ranging from $7.6-15.2 \mathrm{~cm}$ in diameter and water velocities of 0.33 to $1.28 \mathrm{~m} / \mathrm{s}$. The majority of the redds were found in depths of 2-4 m.

Expanded surveys conducted in the fall of 2000 encompassing about $8 \mathrm{~km}$ of the Columbia River below Bonneville Dam did not document any significant spawning activity within the areas surveyed. No fall chinook salmon redds were found in surveyed areas outside the Ives/ Pierce island complex. No chum salmon (O. keta) redds were found to occur in the areas surveyed during 2000 (Note: surveys were limited to deeper sections of Hamilton Slough and near the main river channel). These studies and others demonstrate that physical habitat conditions suitable for spawning by fall chinook salmon exist in confined areas downstream of Bonneville Dam. These conditions are highly regulated by project operations. Thus, any proposed changes in operations, including flow alterations during the spawning period need to be evaluated to minimize the potential impact to fall chinook salmon populations. 


\section{Acknowledgments}

The author would like to thank Scott Titzler and Corey Duberstein for their help in conducting the surveys and analysis of the videotapes. 


\section{Contents}

Executive Summary ......................................................................................... iii

Acknowledgments........................................................................................ V

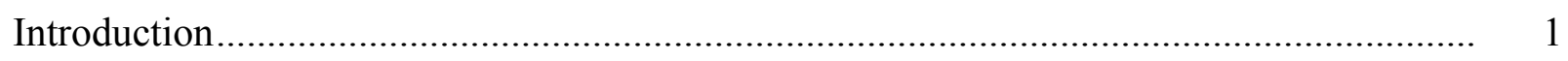

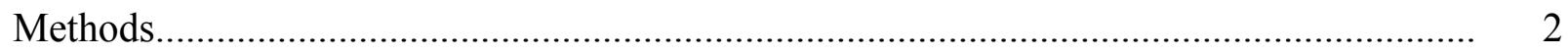

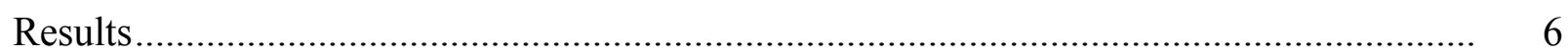

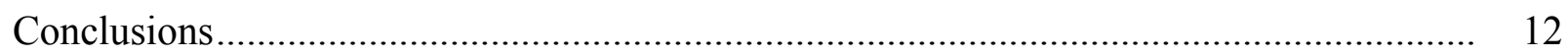

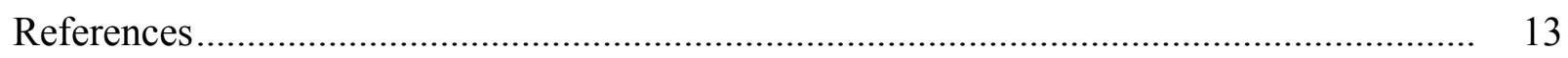

Appendix A ....................................................................................................... A. 1

\section{Figures}

1 Location of primary search zones in relation to Ives and Pierce Islands ................... 2

2 Location of habitat units downstream of Bonneville Dam in 2000 ......................... 3

3 Photo of weighted sled with video camera and lasers used to collect

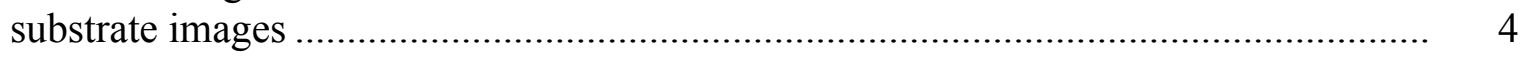

4 Location of fall chinook salmon redds in the mainstem of the Columbia River

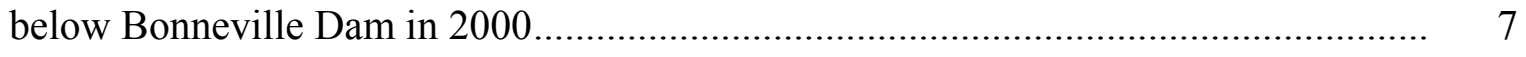

5 Distribution of fall chinook salmon redds in relation to water depth found during the November and December surveys............................................................... 8

6 Dominant substrate classification of fall chinook redds ..................................... 8

7 Map showing areas surveyed within the selected habitat units.............................. 11 


\section{Tables}

1 Substrate categories used for spawning habitat classification ............................... 5

2 Physical characteristics collected at randomly selection redds occurring

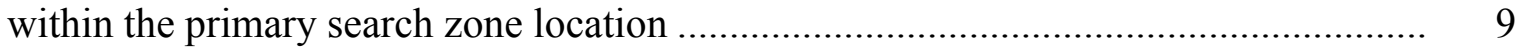

3 Substrate characterization of randomly selected habitat units within the

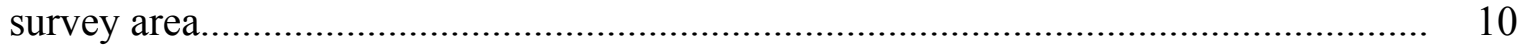

$4 \quad$ Estimated number of fall chinook salmon redds occurring in the primary search zone near Ives and Pierce Island during 1999-2000 .................................. 12 


\section{Introduction}

Fall chinook salmon (Oncorhynchus tshawytscha), thought to originate from Bonneville Hatchery, were first noted to be spawning downstream of Bonneville Dam by Washington Department of Fisheries and Wildlife (WDFW) biologists in 1993 (Hymer 1997). Known spawning areas included gravel beds on the Washington side of the river near Hamilton Creek and Ives Island. The size of this population from 1994 to 1996 was estimated at 1,800 to 5,200 fish (Hymer 1997), and 554 fish in 1998 (Van der Naald et al. 1999). These estimates were based on carcass surveys and visual observation of redds by boat near the shoreline. Pacific Northwest National Laboratory (PNNL) conducted underwater video surveys in the fall of 1999 and 2000 to determine the extent of the fall chinook salmon spawning and to estimate the number of redds occurring in deeper water. Estimates of redds occurring in water depths exceeding $2.2 \mathrm{~m}$ at 143,000 cubic feet per second (kcfs) were 499 in 1999 (Mueller and Dauble 1999) and 567 redds $>2.2 \mathrm{~m}$ at $127 \mathrm{kcfs}$ in 2000 (this study). The majority of the redds found were confined near the main river channel adjacent to Pierce Island.

Chum salmon (O. keta) also have been documented using the mouth of Hamilton Creek and portions of Hamilton Slough for spawning. The majority of chum salmon were found to spawn in shallow water at the mouth of Hamilton Creek adjacent to Ives Island. Estimates of the natural chum salmon spawning population for 1998 were 226 (Van der Naald et al. 1999). Chum salmon spawning near Ives Island are part of the Columbia River evolutionary significant unit (ESU), and are included in the Endangered Species Act of 1973 (ESA) listing in March 1999.

Our main objective of this study was to locate deep water spawning locations of fall chinook salmon in the main Columbia River channel and to collect additional data on physical habitat parameters at spawning sites. The secondary objective was to map any chum salmon redds located in the deep sections of Hamilton Slough. There are several ongoing investigations to define the physical habitat characteristics associated with fall chinook and chum salmon spawning areas downstream of Bonneville Dam. A major concern is to determine what flows (i.e., surface elevations) are necessary to ensure their long-term survival. This objective is consistent with the high priority placed by the Northwest Power Planning Council's Independent Advisory Board and the salmon managers on determining the importance of mainstem habitats to the production of salmon in the Columbia River Basin. 


\section{Methods}

Underwater video surveys were conducted to locate fall chinook salmon redds on November 8-10 and December 5-6, 2000. A separate search was conducted on December 5 within the Hamilton Slough to look for the presence of fall chinook or chum salmon redds. The main objectives of these surveys were to map the extent of fall chinook salmon spawning habitat and collect physical characteristics on the redds found. A primary search zone was established based on existing data from surveys conducted in 1999 (Figure 1). This zone is located approximately $3.5 \mathrm{~km}$ downstream of Bonneville Dam near Columbia River km 228.5. This zone (175 x $625 \mathrm{~m}$ ) was segmented into a series of $25 \mathrm{~m}$ transects (26 total) running perpendicular to the shoreline, and was surveyed during both survey periods.

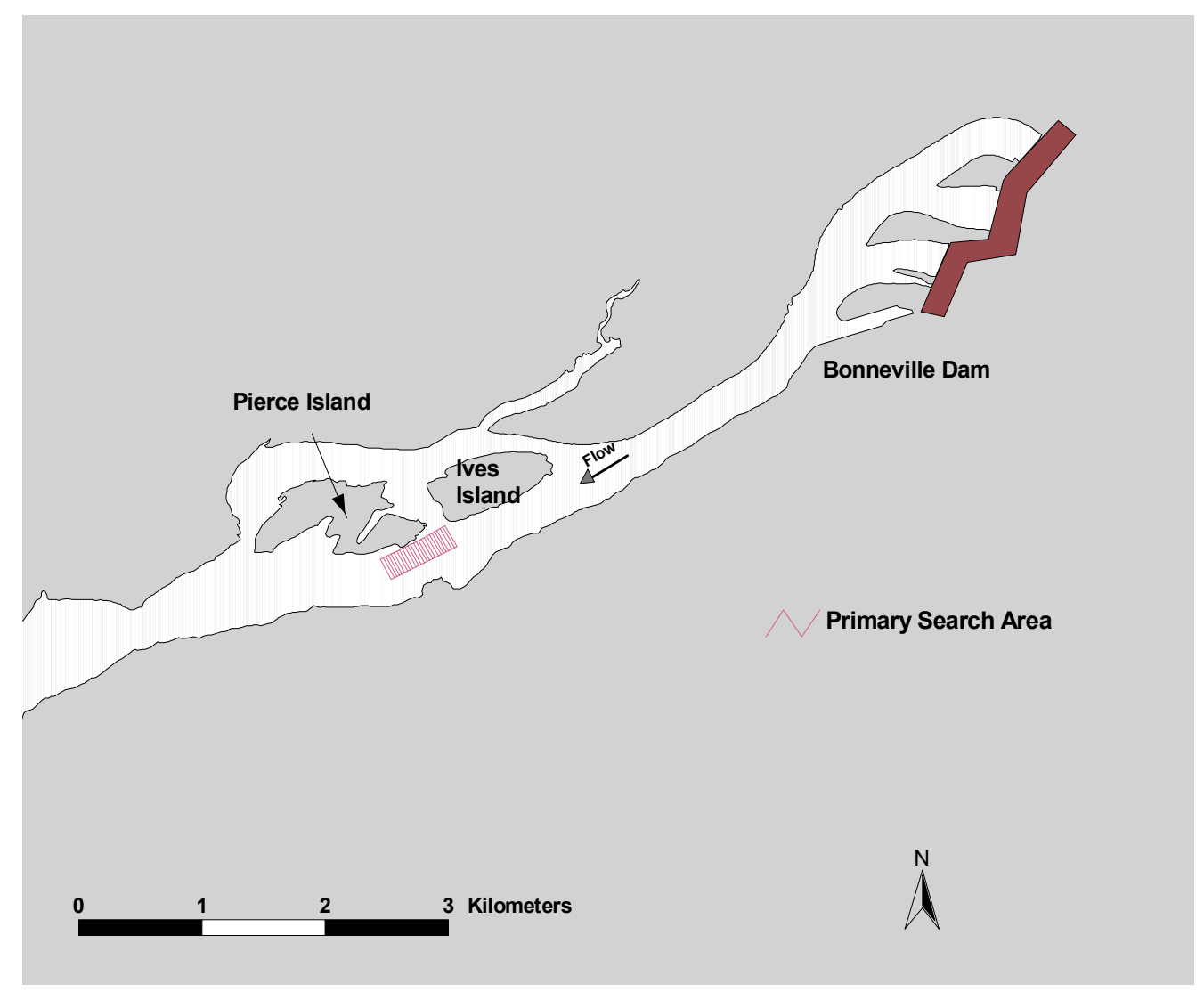

Figure 1. Location of primary search zones in relation to Ives and Pierce Islands

Additional surveys also were conducted in the mainstem Columbia River downstream of Bonneville Dam within a pre-determined section of river ( $\mathrm{rkm}$ 225.3-233.3). The section corresponds to the area emphasized in a physical habitat model being developed by the US Fish and 
Wildlife Service and the USGS Biological Resource Division. We segregated this river section into four habitat types: Island Complex (I2-I6), North Shore (N1, N7-10), River Channel (RC1$\mathrm{RC10}$ ), and South Shore (S1-S10). The 8-km section of river was divided further into ten 609-m segments along the centerline of the river (Figure 2). The sampling schedule included surveys of the following: 1) Island Complex - sampling units I2-I6, which included the primary search zone; 2) North Shore - sampling units included unit N1 and one randomly selected unit from units N7-N10; 3) South Shore - two units randomly selected from S1-S10; and 4) River Channel - three units randomly selected from RC1-RC10. In the case that a randomly selected sampling unit was found to exceed $9.14 \mathrm{~m}$, as did most of the river channel units, the unit immediately upriver or down-river was surveyed, unless that unit already had been surveyed. In the case of irregular bottom or excessive slope, the sampling unit was surveyed where practical. All surveys were conducted by following existing background maps (line transects @ $50 \mathrm{~m}$ intervals) generated with a GIS then exported to a GPS computer program. A total of 10 randomly selected points were selected within each sampling unit surveyed and analyzed for substrate composition and degree of embeddedness.

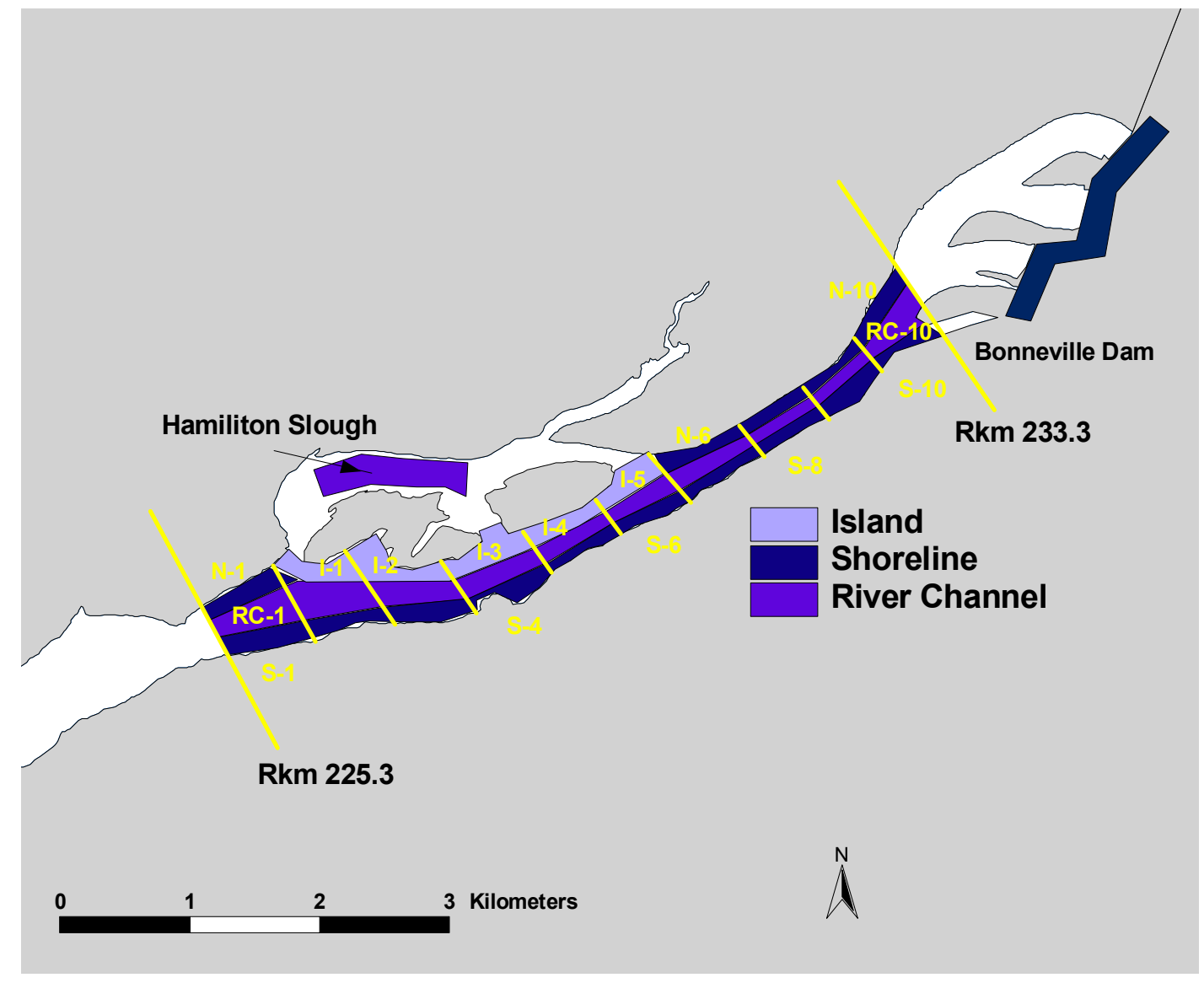

Figure 2. Location of habitat units downstream of Bonneville Dam in 2000 ( $\mathrm{N}$ and $\mathrm{S}=$ shoreline units, I = Island units, $\mathrm{RC}=$ river channel units) 
Information gained from this model will be used to better predict the types and amount and habitat available to fall chinook and chum salmon. Information from prior studies (Mueller and Dauble 1999) conducted on fall chinook spawning in the vicinity of Ives and Pierce Islands were incorporated into the study design. A stratified adaptive sampling strategy (Thompson 1992) was used to optimize resources and obtain more precise estimates of redd population and density of fall chinook salmon spawning below Bonneville Dam.

A mobile underwater video system was used and consisted of a high-sensitivity remote camera (Sony, model HVM-352) attached to a weighted platform (Figure 3). Recordings were made using a Sony model FX710 Hi 8mm recorder located on the survey vessel. Two highresolution monitors were used during the surveys for better viewing of the video obtained by the remote camera. An integrated video/tow cable attached to a manual winch with slip ring mechanism was used to raise and lower the sled to the desired depth. Visual images of redds and bottom substrate were recorded using an underwater video system according to procedures described in Dauble et al. (1999). Limitations on the videography gear precluded the survey of regions $>9 \mathrm{~m}$ in depth.

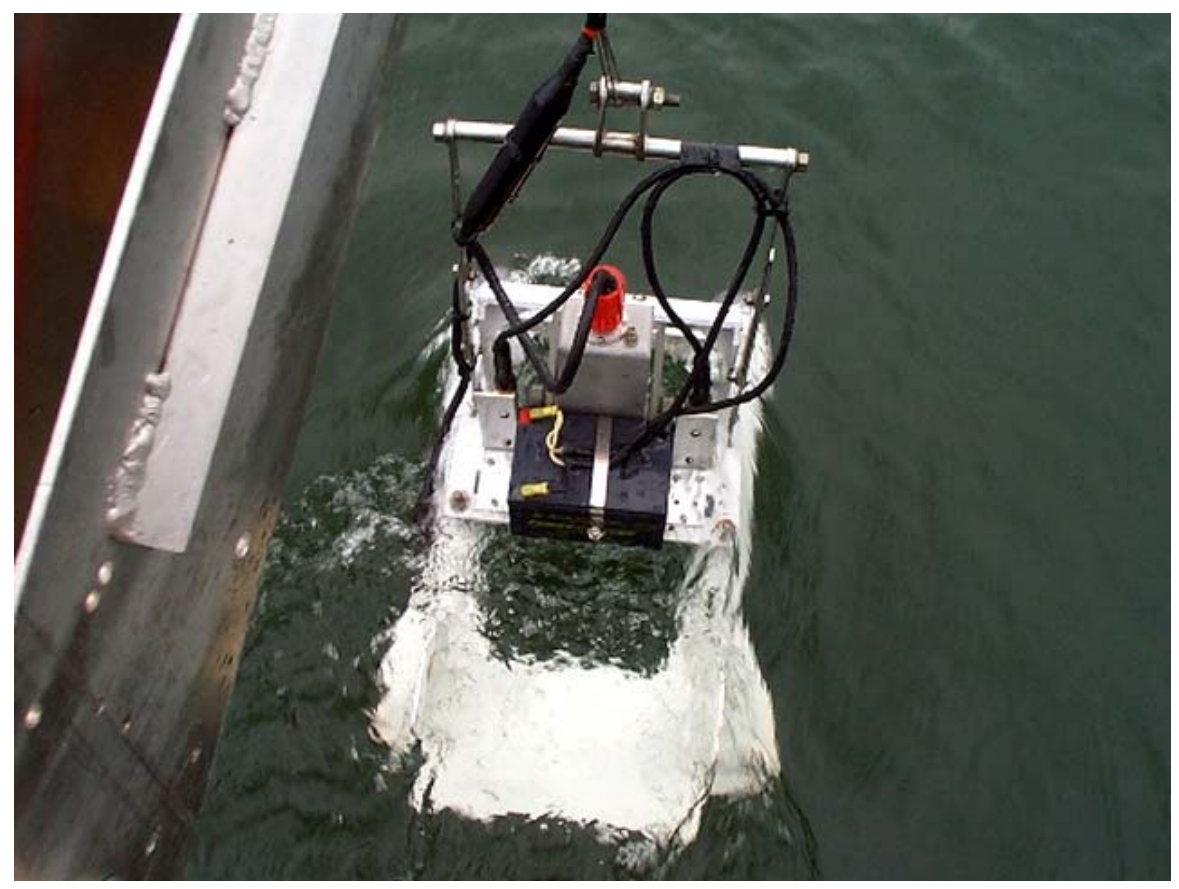

Figure 3. Photo of weighted sled with video camera and lasers used to collect substrate images 
The location for each image (northing and easting) was correlated to the GPS location by a time stamp. An on-board, real-time differential GPS (Trimble Pathfinder ${ }^{\mathrm{TM}}$ Pro XR) was used to collect positional data and to navigate pre-set transect grids during the surveys. The integrated GPS beacon receiver and antenna provided GPS corrections for calculating sub-meter accuracy (approximately $0.5 \mathrm{~m}$ ). The system's software (ASPEN) displayed a background map of the study site on a personal computer so researchers could navigate to site locations on a predetermined transect line and visually verify data accuracy in the field.

To ascertain the dominant substrate sizes obtained by the video camera, two underwater lasers (C Map Systems model HL6312G), pointed downward $18.4 \mathrm{~cm}$ apart, were attached to the underwater platform, and provided a reference scale within the camera image (Figure 3 ). The distance from the camera lens to the substratum ranged from 0.9 to $1.4 \mathrm{~m}$, providing an effective view path of $\sim 2.7 \mathrm{~m}^{2}$ during low turbidity conditions. The substratum for each redd mapped was estimated using the recorded videotapes and corresponding GPS time stamp. Images were digitized and measurements of the grain sizes were obtained by using a software imaging program (Optimas ${ }^{\circledR}$ ). Particle size was determined by taking an average of the dominant substratum type within a camera field of view at each redd based on long-axis diameter. The substrate size for each redd was classified according to three general size categories (Table 1).

Table 1. Substrate categories used for spawning habitat classification (modified from Platts et al. 1983)

\begin{tabular}{||c|l|c||}
\hline Category & Sediment Classification & $\begin{array}{c}\text { Long Axis Diameter of Individual } \\
\text { Substrate }(\mathrm{cm})\end{array}$ \\
\hline \hline 1 & Fines, silt & $<0.61$ \\
\hline 2 & Gravel & $0.6-7.6$ \\
\hline 3 & Medium cobble & $7.6-15.2$ \\
\hline 4 & Large cobble & $15.2-30.5$ \\
\hline 5 & Boulder & $>30.5$ \\
\hline
\end{tabular}

Based on existing literature of fall chinook salmon redd areas, we determined that the minimum average size redd to be approximately $10 \mathrm{~m}^{2}$ (Burner 1951; Chapman 1983; Visser 1999). Based on this value, any redds mapped that fell within a $\sim 1.8 \mathrm{~m}$ radius of a nearby redd was omitted from the overall redd count. This was done to reduce the probability that a redd would be counted more than once for all surveys. In addition, based on the number of deep water redds counted using the video camera within our primary search zone we estimated the number of redds which may have been constructed through this area. The estimates were calculated using the average number of redds found at each of the 26 transects surveyed which 
averaged $85 \mathrm{~m}$ in length. The total fall chinook salmon redd estimates do not include redds found by other agencies in water depths $<1.2 \mathrm{~m}$.

Velocity data was collected using a Marsh McBirney model 2000 flow-meter attached to the camera sled. Turbidity was recorded using a LaMotte model 2008 turbidimeter. Changes in background contrast, bed elevation, or substrate composition were the primary criteria used to determine spawning activity. Recorded tapes were reviewed in detail at the PNNL computer lab using a high-resolution monitor. Bathymeteric data was obtained using a one-dimensional, unsteady river flow and water quality computer model MASS1 (Modular Aquatic Simulation System 1D) developed at PNNL.

\section{Results}

Initial deepwater redd surveys of the main channel near Ives and Pierce Islands were completed on November 8-10, 2000, which encompassed the peak spawning date of November 9 for fall chinook salmon. Turbidity values averaged 2.7 nephelometric turbidity units (NTU). River flows recorded at Bonneville Dam during this survey ranged from 120-128 kcfs and water surface elevation recorded at Staff Gauge 1 near Hamilton Creek ranged from 0.21-0.36 m. A total of 81 fall chinook salmon redds were mapped and found to occur adjacent to the southern portion of Pierce Island (Figure 4). Several redds were also found at the downstream of the primary search near the main river channel at rkm 227.6. Due to low river flows and shallow water, no video surveys were conducted in the channel between the islands or in the Hamilton Slough.

The second deepwater fall chinook salmon redd survey was completed on December 5-6, 2000. River flows averaged $128 \mathrm{kcfs}$ and surface elevation recorded at Staff Gauge 1 was $0.26 \mathrm{~m}$. Turbidity values averaged 3.36 NTU. An additional 70 fall chinook salmon redds were found on this survey occurring mainly within are near the primary search zone, including 7 redds mapped within Hamilton Slough (Figure 4). Due to low river flows during the sampling periods, we were not able to survey the area between Ives and Pierce Islands. No fall chinook salmon redds were found adjacent to Ives Island towards the river channel. A listing of all fall chinook salmon redd coordinates found near the main river channel along with depth and dominate substrate type are located in Appendix A.

No chum salmon redds were found within the Hamilton Slough during our video searches conducted in December. The surveys were conducted in the relatively deeper sections of the slough downstream from the mouth of Hamilton Creek where the majority of chum salmon 
spawning is known to occur. The redds found during the December survey were classified as fall chinook salmon redds based on nearby carcasses.

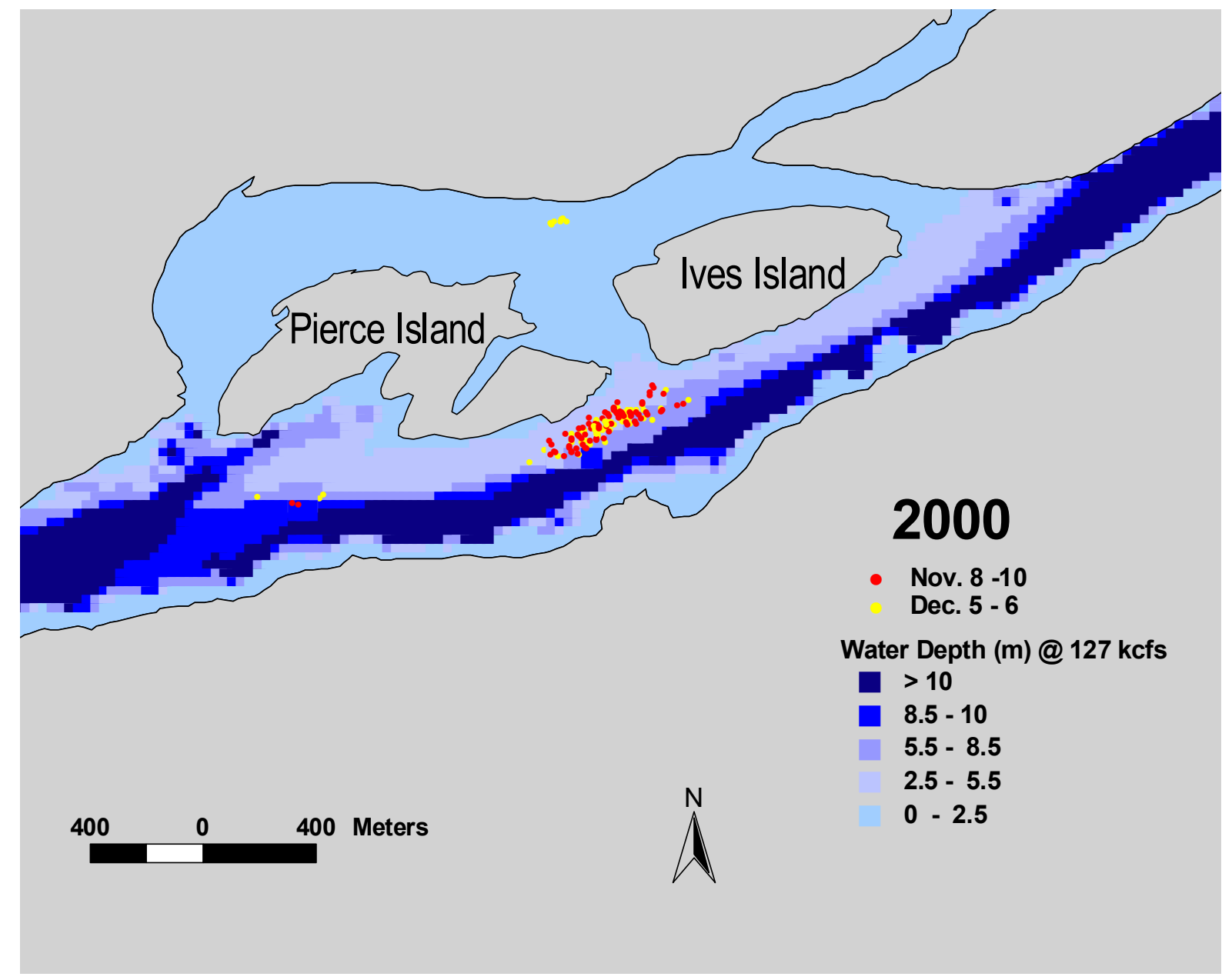

Figure 4. Location of fall chinook salmon redds in the mainstem of the Columbia River below Bonneville Dam in 2000 (Only main channel surveys were conducted on November 8-10.)

Fall chinook redds were found in depths ranging from 1.2-6.4 $\mathrm{m}$ with the majority $(55 \%)$ found in water depths of 2-4 $\mathrm{m}$ (Figure 5). The dominant substrate size was classified for the majority of redds $(\mathrm{n}=96)$ found during the November and December surveys. The dominant substrate consisted predominately (66\%) of medium cobbles with large cobble being the second most utilized (Figure 6).

Mean near-bed point velocities obtained at 22 randomly selected redds located within the primary search zone near Pierce Island (Table 2). The point velocities measured near the riverbed ranged from 0.33 to $1.28 \mathrm{~m} / \mathrm{s}$ (mean $0.85 \mathrm{~m} / \mathrm{s}$ ). 


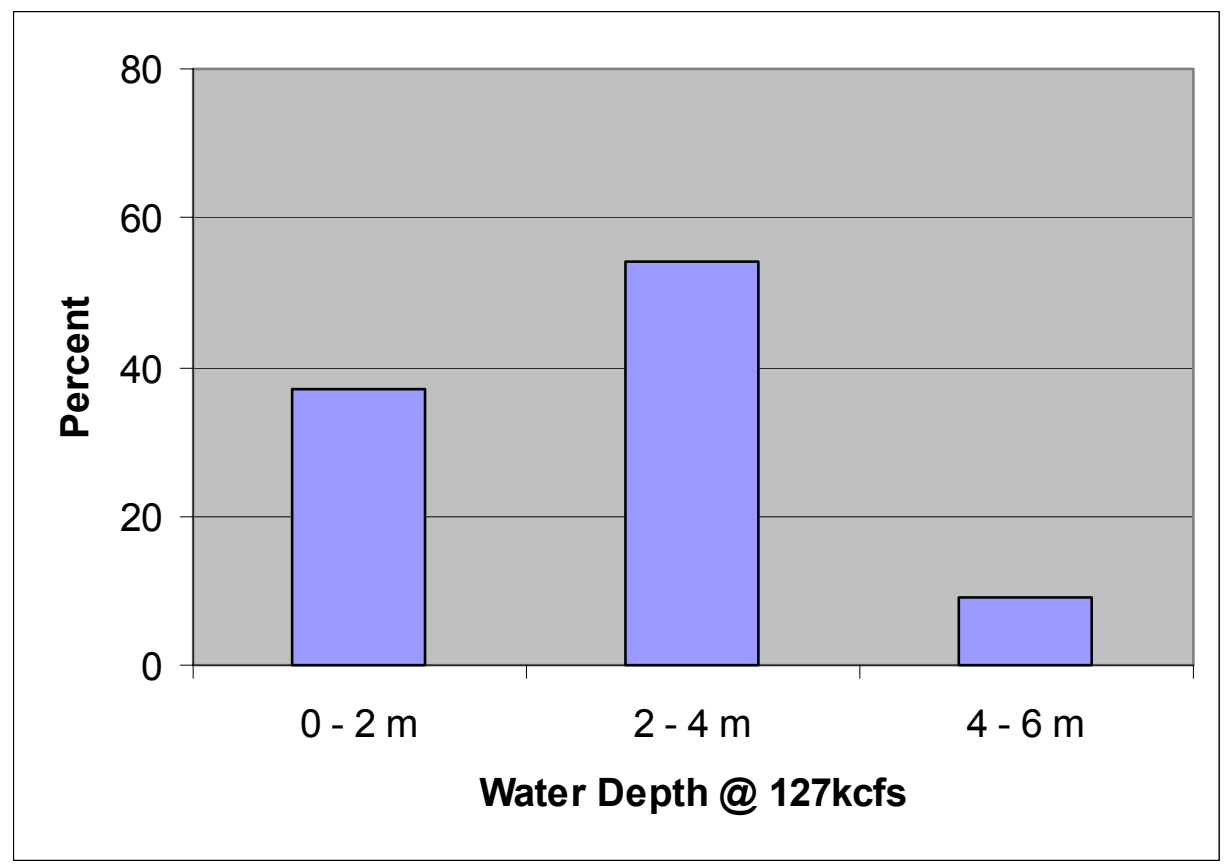

Figure 5. Distribution of fall chinook salmon redds $(n=151)$ in relation to water depth found during the November and December surveys

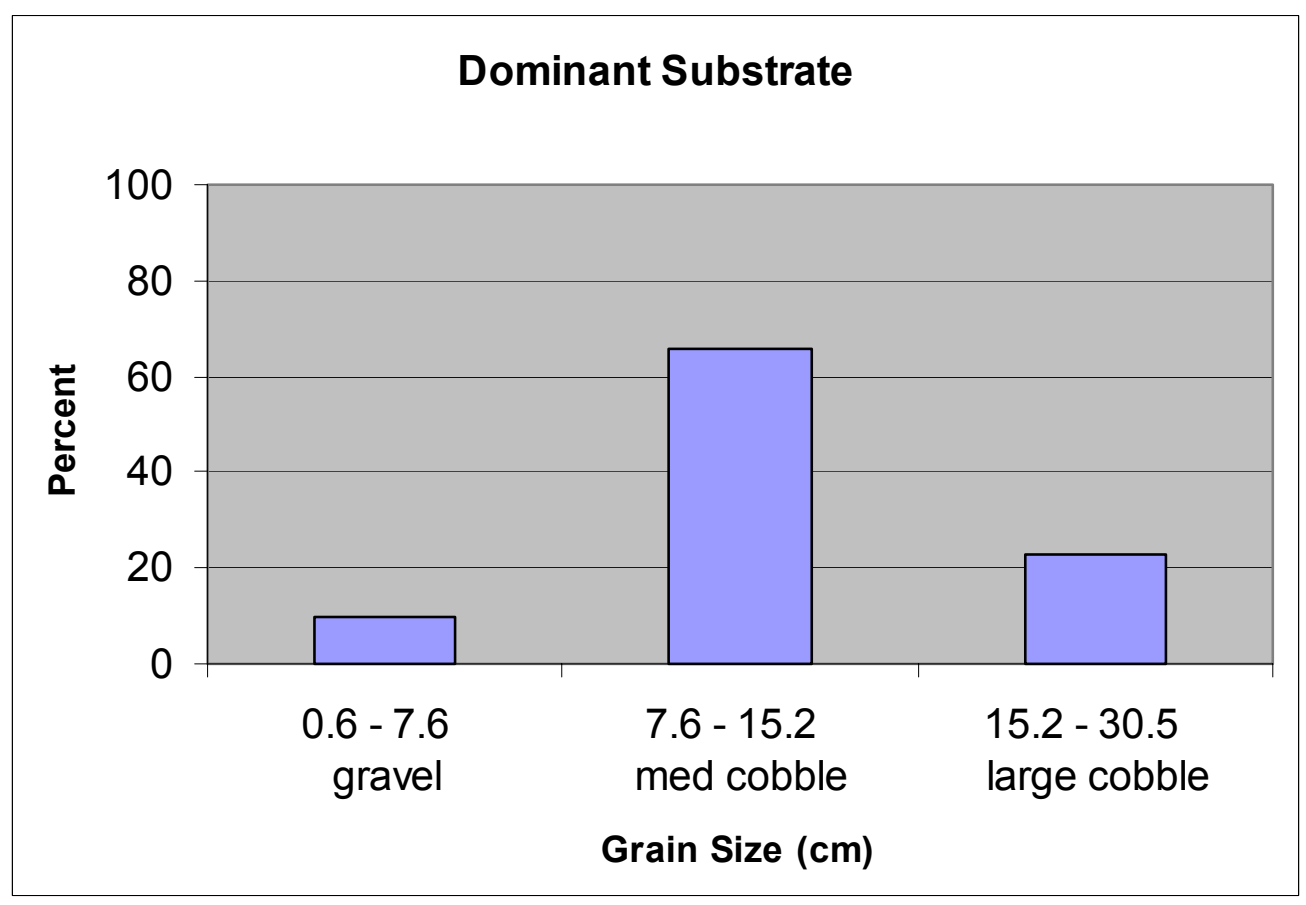

Figure 6. Dominant substrate classification of fall chinook redds (number of redds $=96$ ) 
Table 2. Physical characteristics collected at randomly selection redds occurring within the primary search zone location (coordinates: NAD 1983 WA South)

\begin{tabular}{|c|c|c|c|c|}
\hline $\begin{array}{l}\text { Northing } \\
\text { (m) }\end{array}$ & $\begin{array}{l}\text { Easting } \\
(\mathrm{m})\end{array}$ & $\begin{array}{l}\text { Depth } \\
(\mathrm{m})\end{array}$ & $\begin{array}{l}\text { Substrate } \\
\text { Category }\end{array}$ & $\begin{array}{l}\text { Bed Velocity } \\
\qquad(\mathrm{m} / \mathrm{s})\end{array}$ \\
\hline 32892.48 & 383044.08 & 2.4 & 3 & 0.75 \\
\hline 32909.81 & 383062.63 & 2.4 & N/A & 0.90 \\
\hline 32924.88 & 383110.22 & 3.0 & $\mathrm{~N} / \mathrm{A}$ & 0.50 \\
\hline 32919.87 & 383041.97 & 2.0 & 2 & 0.93 \\
\hline 32871.06 & 383035.17 & 2.4 & 3 & 0.61 \\
\hline 32874.56 & 383026.99 & 2.7 & 3 & 1.00 \\
\hline 32867.93 & 383031.03 & 2.7 & 4 & 0.90 \\
\hline 32858.47 & 383002.13 & 2.4 & 3 & 0.89 \\
\hline 32839.22 & 382973.50 & 2.4 & 3 & 1.10 \\
\hline 32852.53 & 382992.94 & 2.1 & 2 & 1.12 \\
\hline 32877.94 & 383000.17 & 1.8 & 3 & 1.28 \\
\hline 32888.06 & 383038.63 & 2.0 & 3 & 1.22 \\
\hline 32891.93 & 383053.42 & 2.7 & 3 & 0.85 \\
\hline 32919.85 & 383063.96 & 2.3 & 3 & 0.82 \\
\hline 32841.51 & 382958.21 & 2.1 & 3 & 0.33 \\
\hline 32858.08 & 382934.97 & 1.4 & 3 & 0.86 \\
\hline 32620.22 & 381989.22 & 4.0 & N/A & 0.46 \\
\hline 32607.11 & 381971.86 & 4.3 & N/A & 1.05 \\
\hline 32910.94 & 383043.55 & 1.5 & 2 & 2.71 \\
\hline 32841.50 & 382958.21 & 2.1 & 3 & 1.08 \\
\hline 32853.65 & 382963.77 & 2.1 & 3 & 2.66 \\
\hline
\end{tabular}

Results from the randomly selected habitat units were quite variable in bottom composition and suggested very little suitable fall chinook salmon habitat was present in the surveyed areas (Table 3). Due to depth, bottom variability, and back-eddies, only small sections of most survey units could be effectively surveyed using the boat deployed video system (Figure 7). For the north shoreline section upstream of Ives Island up to rkm 233.3 unit N-7 was surveyed and was comprised of mainly a rip/rap extending to water depths near $4.6 \mathrm{~m}$. Beyond this depth the substratum consisted of large cobble with a high degree of slope. The remaining north shoreline 
section (N-1), downstream of Pierce Island, was characterized by lower water velocities and a silt/sand substratum. For the most part, the substrate composition of the south shoreline units S-4 and S-9 contained only small pockets of cobbles which fall into the range preferred by fall chinook salmon for spawning purposes. These areas were generally located near back-eddies and on bedrock shelves that sloped steeply to the thalweg. The river channel units were generally to deep to obtain adequate video images and exceeded the limits of the video system ( $>9 \mathrm{~m})$ with the exception of units RC-2 and RC-3 located adjacent to the lower end of Pierce Island. Five redds were found in zone RC-2 near rkm 227.6. These redds occurred in an area with cobbles and water velocities similar to fall chinook salmon redds found in the primary spawning area $\sim 100$ m upstream.

Table 3. Substrate characterization of randomly selected habitat units within the survey area $(\mathrm{Rkm} 225.3-233.3)$

\begin{tabular}{||c|l|l||}
\hline $\begin{array}{c}\text { Location } \\
\text { (refer to figure 7) }\end{array}$ & $\begin{array}{c}\text { Dominant Substrate } \\
\text { Range }\end{array}$ & \multicolumn{1}{c|}{ Characteristics } \\
\hline \hline I-5 & Large cobble & Low embeddedness, lower velocities. \\
\hline N-1 & Silt to large cobble & $\begin{array}{l}\text { Generally silted with high degree of } \\
\text { embeddedness. }\end{array}$ \\
\hline N-7 & Gravel-large cobble & High degree of slope, rip/rap at shoreline. \\
\hline RC-2 & Silt-large cobble & Low embeddedness clean cobbles. \\
\hline RC-3 & Gravel-large cobble & Mostly gravels, moderate embeddedness. \\
\hline S-4 & Gravel-large cobble & $\begin{array}{l}\text { Only small pocket of suitable habitat, high } \\
\text { degree of slope. }\end{array}$ \\
\hline S-9 & Cobble-bedrock & $\begin{array}{l}\text { Generally larger cobble and boulder, high } \\
\text { slope. }\end{array}$ \\
\hline
\end{tabular}




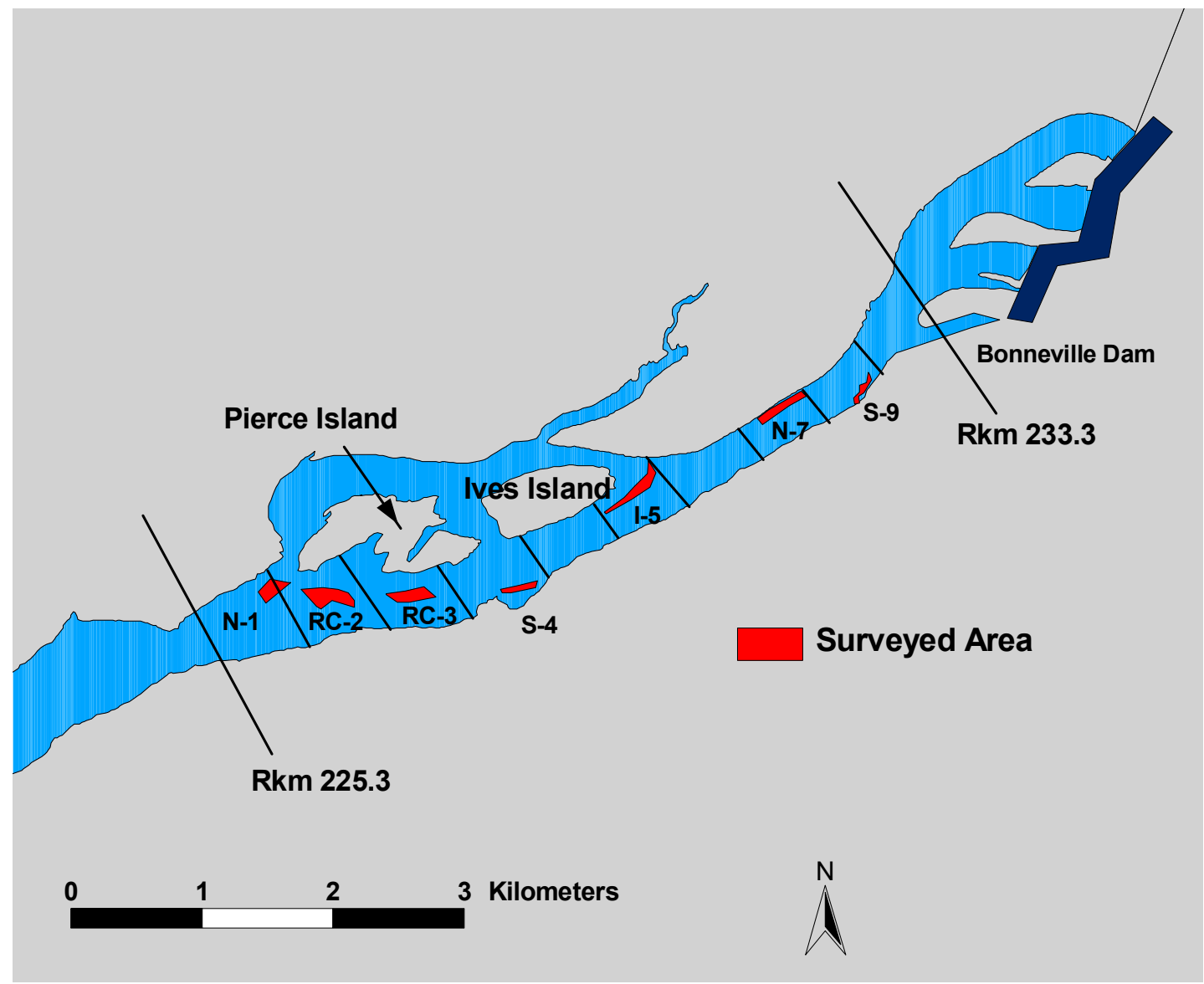

Figure 7. Map showing areas surveyed within the selected habitat units (rkm 226-133.3)

Using the number of redds found during both surveys periods, we extrapolated these counts to estimate a total number of redds constructed within the primary search zone. These estimates were calculated by taking the average number of redds found at each of the 26 transect lines and assuming normal distribution within the entire survey area $\left(109,375 \mathrm{~m}^{2}\right)$ based on a redd area of $10 \mathrm{~m}^{2}$. Using the highest redd count during 2000, we estimated that 787 fall chinook salmon redds were constructed at water depths exceeding $2 \mathrm{~m}$ at a river discharge of $\sim 127 \mathrm{kcfs}$ in the primary search zone described earlier (Table 4 ). State agency personnel counted $\sim 100$ additional fall chinook salmon redds in the area between Ives and Pierce Islands by wading or observation by boat. 
Table 4. Estimated number of fall chinook salmon redds occurring in the primary search zone near Ives and Pierce Islands during 1999-2000

\begin{tabular}{||l|c|c|c|c||}
\hline \hline \multicolumn{1}{|c|}{ Survey Date } & $\begin{array}{c}\text { Estimated } \\
\text { Coverage } \\
\text { within Primary } \\
\text { Zone (sq m) }\end{array}$ & $\begin{array}{c}\text { Number of } \\
\text { Redds Found }\end{array}$ & $\begin{array}{c}\text { Ratio of Redds } \\
\text { per Area }\end{array}$ & $\begin{array}{c}\text { Extrapolated } \\
\text { Redd Estimate }\end{array}$ \\
\hline \hline Nov. 9-10, 1999 & 10,816 & 36 & 0.0033 & 359 \\
\hline Dec. 1-2, 1999 & 9,318 & 64 & 0.0069 & 754 \\
\hline Nov. 8-10, 2000 & 11,648 & 76 & 0.0065 & 710 \\
\hline Dec. 5-6, 2000 & 7,072 & 51 & 0.0072 & 787 \\
\hline
\end{tabular}

\section{Conclusions}

We mapped an estimated 151 redds on surveys conducted in November and December 2000. As in 1999, the primary deep water spawning activity was concentrated adjacent to Pierce Island. Fall chinook salmon redds were found to depths of $6.4 \mathrm{~m}$, velocities of 0.32 to $1.3 \mathrm{~m} / \mathrm{sec}$, and mainly over cobble substrate $(7.6-15.2 \mathrm{~cm})$. These values are comparable to the results we obtained during the 1999 surveys (Mueller and Dauble 2000). The highest extrapolated redd estimates for the known spawning area during 1999 was 562 redds, which suggest a spawning population of 1,910 fish (using a redd to adult ratio of 3.4). The total estimated area utilized by adult fall chinook salmon based on our surveys was 6.28 ha during 2000 after accounting for redds found near the lower end of Pierce Island. This estimate included redds found from 1.5$6.4 \mathrm{~m}$ in depth at a flow of $127 \mathrm{kcfs}$ at Bonneville Dam. This area is slightly larger than the 4.0 ha estimated spawning habitat reported in 1999.

Analysis of the additional surveys made throughout the USGS Biological Resource Division habitat model region indicated minimal areas of suitable habitats based on depth, slope, and substrate. This conclusion was based on limited area coverage due to the stratified sampling regime. We attempted to survey additional areas located along the south shoreline where depth and flow permitted but found only isolated pockets near units S-4 and S-9 where surveys could be conducted. It seems unlikely that fall chinook salmon spawning would occur in any of the surveyed areas with the exception of RC-2 and RC-3. 


\section{References}

Burner, C. J. 1951. Characteristics of spawning nests of Columbia River salmon. Fishery Bulletin 61, Volume 52. U.S. Fish and Wildlife Service, Washington, D.C.

Chapman, D. W., D. E. Weitkamp, T. L. Welsh, and T. H. Schaldt. 1983. Effects of minimum flow regimes on fall chinook salmon spawning at Vernita Bar 1978-1982. Don Chapman Consultants, McCall, ID and Parametrix, Inc., Bellevue, WA.

Dauble, D. D., R. P. Mueller, R. L. Johnson, W. V. Mavros, and C. S. Abernethy. 1999. Surveys of fall chinook salmon spawning downstream of Lower Snake River hydroelectric projects. Summary Report for 1993-1998. Prepared by Pacific Northwest Laboratory for the U.S. Army Corps of Engineers, Walla Walla District, Walla Walla, WA.

Endangered Species Act. 1973. Public Laws 93-205 through 100-707, as amended, 87 Stat. 884, 16 USC 1531 et seq.

Hymer, J. 1997. Results of studies on chinook spawning in the mainstem Columbia River below Bonneville Dam. Columbia River Progress Report 97-9. Washington Department of Fish and Wildlife, Battle Ground, WA.

Mueller R.P, and D.D. Dauble. 1999. Evidence of deepwater spawning of fall chinook salmon spawning near Ives and Pierce Island of the Columbia River, Annual 1999, Report to Bonneville Power Administration, Project No. 199900304,19 electronic pages (BPA Report DOE/BP00000652-2).

Platts, W. S., W. F. Megahan, and G. W. Minshall. 1983. Methods for evaluating stream, riparian, and biotic conditions. U.S Forest Service Technical report INT-138. U.S. Forest Service, Washington, D.C.

Thompson, Steven K. 1992. Sampling. Wiley and Sons, NY.

Van der Naald, W., B. Spellman, and R. Clark. 1999. Evaluation of fall chinook and chum salmon spawning below Bonneville, The Dalles, and McNary Dams. Report to the Bonneville Power Administration, Project No. 199900302, 43 electronic pages (BPA Report DOE/BP15007-1). 
Visser, R. H. 1999. Utilizing remotely sensed imagery and GIS to monitor and research salmon spawning: A case study of the Hanford Reach fall chinook (Oncorhynchus tshawytscha). Masters Thesis. Central Washington State University, Ellensburg, WA. 
Appendix A 


\section{Appendix A}

PNNL Redd Coordinate Description

\begin{tabular}{||l|l||}
\hline \multicolumn{1}{|c|}{ Projection } & \multicolumn{1}{c|}{ Stateplane } \\
\hline \hline Zone & 5626 \\
\hline Datum & NAD83 \\
\hline Units & Meters \\
\hline Vertical Datum & NGVD29 \\
\hline
\end{tabular}

\begin{tabular}{|c|c|c|c|c|}
\hline & Northing & Easting & Depth (m) & $\begin{array}{c}\text { Dominant Substrate } \\
\text { Category }\end{array}$ \\
\hline 1 & 32755.243 & 382797.831 & 2.4 & 3 \\
\hline 2 & 32760.640 & 382790.357 & 2.4 & $\mathrm{n} / \mathrm{a}$ \\
\hline 3 & 32809.752 & 382789.376 & 1.5 & 2 \\
\hline 4 & 32794.345 & 382794.162 & 1.8 & 3 \\
\hline 5 & 32772.036 & 382803.079 & 2.4 & 4 \\
\hline 6 & 32770.490 & 382809.220 & 2.4 & 3 \\
\hline 7 & 32757.724 & 382842.237 & 3.0 & 4 \\
\hline 8 & 32768.747 & 382866.328 & 3.0 & 4 \\
\hline 9 & 32773.588 & 382866.571 & 2.7 & 3 \\
\hline 10 & 32784.628 & 382859.389 & 2.4 & 4 \\
\hline 11 & 32788.853 & 382859.723 & 2.4 & 3 \\
\hline 12 & 32836.135 & 382844.379 & 1.5 & 3 \\
\hline 13 & 32818.711 & 382866.493 & 1.8 & 3 \\
\hline 14 & 32813.103 & 382867.511 & 2.1 & 3 \\
\hline 15 & 32783.018 & 382885.886 & 2.4 & 4 \\
\hline 16 & 32764.305 & 382890.468 & 3.7 & 3 \\
\hline 17 & 32780.069 & 382921.417 & 3.7 & 4 \\
\hline 18 & 32785.181 & 382915.105 & 3.4 & 4 \\
\hline 19 & 32795.402 & 382906.712 & 3.0 & 3 \\
\hline 20 & 32816.651 & 382901.915 & 2.4 & 3 \\
\hline 21 & 32824.921 & 382893.070 & 1.8 & 4 \\
\hline
\end{tabular}

A. 1 


\begin{tabular}{||l|l|l|l|c||}
\hline & Northing & Easting & Depth $(\mathrm{m})$ & $\begin{array}{c}\text { Dominant Substrate } \\
\text { Category }\end{array}$ \\
\hline \hline 22 & 32831.486 & 382890.095 & 1.8 & 3 \\
\hline 23 & 32854.547 & 382895.015 & 1.2 & 3 \\
\hline 24 & 32858.518 & 382907.006 & 1.2 & 2 \\
\hline 25 & 32832.509 & 382914.494 & 1.8 & 3 \\
\hline 26 & 32808.978 & 382930.942 & 3.0 & 3 \\
\hline 27 & 32805.213 & 38963.978 & 4.3 & 4 \\
\hline 28 & 32813.721 & 382954.742 & 3.7 & 3 \\
\hline 29 & 32818.419 & 382953.580 & 3.0 & 3 \\
\hline 30 & 32852.495 & 382938.257 & 2.4 & 3 \\
\hline 31 & 32869.376 & 382927.836 & 1.8 & 3 \\
\hline 32 & 32893.927 & 382929.092 & 1.2 & 3 \\
\hline 33 & 32868.958 & 382952.446 & 1.5 & 3 \\
\hline 36 & 32850.573 & 382965.230 & 2.1 & 3 \\
\hline 37 & 32818.126 & 382979.972 & 2.7 & 3 \\
\hline 38 & 32845.266 & 382996.647 & 2.4 & 3 \\
\hline 39 & 32861.678 & 382988.730 & 2.1 & 3 \\
\hline 40 & 32889.542 & 382976.417 & 1.8 & 3 \\
\hline 41 & 32910.716 & 382984.028 & 1.2 & 3 \\
\hline 42 & 32903.396 & 382992.101 & 1.5 & 3 \\
\hline 43 & 32897.149 & 382998.740 & 1.5 & 3 \\
\hline 44 & 32869.636 & 383006.590 & 1.8 & 3 \\
\hline 45 & 32890.173 & 383032.672 & 2.4 & 3 \\
\hline 46 & 32897.759 & 383032.677 & 2.1 & 3 \\
\hline 47 & 32903.644 & 383027.724 & 2.1 & 3 \\
\hline 48 & 32910.611 & 383023.359 & 1.8 & 3 \\
\hline 49 & 32916.639 & 383018.236 & 1.5 & 3 \\
\hline 50 & 32920.705 & 383017.188 & 1.5 & 3 \\
\hline 51 & 32926.902 & 383017.146 & 1.2 & 3 \\
\hline 52 & 32944.689 & 383027.967 & 1.2 & 3 \\
\hline 53 & 32914.257 & 383039.614 & 1.5 & 3 \\
\hline 54 & 32908.267 & 383041.775 & 1.8 & 3 \\
\hline 55 & 32904.433 & 383045.051 & 2.4 & 3 \\
\hline 56 & 32896.090 & 383049.650 & 2.4 & 3 \\
\hline \hline
\end{tabular}

A. 2 


\begin{tabular}{|c|c|c|c|c|}
\hline & Northing & Easting & Depth (m) & $\begin{array}{c}\text { Dominant Substrate } \\
\text { Category }\end{array}$ \\
\hline 57 & 32874.528 & 383059.244 & 3.0 & 3 \\
\hline 58 & 32866.896 & 383064.822 & 3.0 & 4 \\
\hline 59 & 32868.155 & 383096.592 & 4.0 & 3 \\
\hline 60 & 32880.947 & 383092.233 & 3.7 & 3 \\
\hline 61 & 32898.003 & 383078.172 & 3.0 & 4 \\
\hline 62 & 32903.714 & 383077.128 & 3.0 & 2 \\
\hline 63 & 32908.293 & 383074.869 & 3.0 & 3 \\
\hline 64 & 32908.873 & 383096.882 & 2.7 & 3 \\
\hline 65 & 32900.207 & 383103.204 & 3.0 & 3 \\
\hline 66 & 32887.614 & 383112.123 & 3.7 & 3 \\
\hline 67 & 32899.761 & 383134.397 & 3.7 & 4 \\
\hline 68 & 32910.083 & 383131.759 & 3.7 & 4 \\
\hline 69 & 32939.596 & 383119.506 & 2.7 & $\mathrm{n} / \mathrm{a}$ \\
\hline 70 & 32943.123 & 383115.371 & 2.7 & $\mathrm{n} / \mathrm{a}$ \\
\hline 71 & 32913.776 & 383184.941 & 4.6 & 3 \\
\hline 72 & 32918.877 & 383186.878 & 4.6 & 3 \\
\hline 73 & 32971.511 & 383141.934 & 2.4 & $\mathrm{n} / \mathrm{a}$ \\
\hline 74 & 32980.490 & 383141.766 & 1.8 & 3 \\
\hline 75 & 33006.468 & 383153.495 & 1.5 & 2 \\
\hline 76 & 32999.290 & 383154.790 & 1.8 & 2 \\
\hline 77 & 32976.491 & 383193.996 & 2.7 & 2 \\
\hline 78 & 32937.421 & 383239.929 & 4.3 & 4 \\
\hline 79 & 32941.011 & 383262.646 & 4.6 & 3 \\
\hline 82 & 32610.085 & 381752.750 & 4.0 & 3 \\
\hline 83 & 32735.769 & 382717.623 & 2.4 & 3 \\
\hline 84 & 32776.828 & 382772.069 & 1.5 & 2 \\
\hline 85 & 32778.254 & 382798.095 & 1.8 & 3 \\
\hline 86 & 32757.832 & 382816.640 & 2.7 & 4 \\
\hline 87 & 32761.325 & 382894.840 & 3.4 & 4 \\
\hline 88 & 32802.630 & 382865.783 & 1.5 & 3 \\
\hline 89 & 32836.455 & 382868.110 & 1.5 & 3 \\
\hline 90 & 32805.281 & 382902.910 & 2.4 & 3 \\
\hline 91 & 32846.678 & 382895.479 & 1.5 & 3 \\
\hline
\end{tabular}

\section{A. 3}




\begin{tabular}{|c|c|c|c|c|}
\hline & Northing & Easting & Depth (m) & $\begin{array}{c}\text { Dominant Substrate } \\
\text { Category }\end{array}$ \\
\hline 92 & 32848.584 & 382909.149 & 1.5 & 3 \\
\hline 93 & 32838.324 & 382910.992 & 1.8 & $\mathrm{n} / \mathrm{a}$ \\
\hline 94 & 32809.660 & 382917.474 & 2.4 & 3 \\
\hline 95 & 32794.427 & 382931.798 & 3.0 & 4 \\
\hline 96 & 32825.011 & 382958.521 & 2.1 & 3 \\
\hline 97 & 32829.781 & 382958.976 & 2.1 & 4 \\
\hline 98 & 32836.825 & 382954.926 & 1.8 & 3 \\
\hline 99 & 32848.697 & 382949.085 & 1.8 & 3 \\
\hline 100 & 32855.394 & 382950.689 & 1.8 & 4 \\
\hline 101 & 32859.094 & 382946.481 & 1.5 & $\mathrm{n} / \mathrm{a}$ \\
\hline 102 & 32884.033 & 382953.040 & 1.5 & 3 \\
\hline 103 & 32875.473 & 382955.498 & 1.5 & 3 \\
\hline 104 & 32854.869 & 382968.900 & 2.4 & 3 \\
\hline 105 & 32848.112 & 382975.619 & 4.0 & 4 \\
\hline 106 & 32804.534 & 382986.967 & 3.0 & 4 \\
\hline 107 & 32820.436 & 383016.693 & 3.0 & 4 \\
\hline 108 & 32848.927 & 383004.017 & 2.7 & 4 \\
\hline 109 & 32858.396 & 382993.154 & 2.4 & 3 \\
\hline 110 & 32866.808 & 382990.619 & 2.1 & 3 \\
\hline 111 & 32880.449 & 382985.626 & 1.8 & 3 \\
\hline 112 & 32900.593 & 382996.733 & 1.5 & $\mathrm{n} / \mathrm{a}$ \\
\hline 113 & 32874.287 & 383006.652 & 1.8 & 4 \\
\hline 114 & 32866.035 & 383016.473 & 1.8 & 3 \\
\hline 115 & 32848.731 & 383027.639 & 3.0 & 3 \\
\hline 116 & 32879.530 & 383044.959 & 2.7 & 3 \\
\hline 117 & 32893.994 & 383038.008 & 2.4 & 3 \\
\hline 118 & 32884.581 & 383046.447 & 1.8 & 4 \\
\hline 119 & 32925.801 & 383030.258 & 1.2 & 3 \\
\hline 120 & 32910.302 & 383045.851 & 1.8 & 4 \\
\hline 121 & 32904.225 & 383059.031 & 2.1 & 3 \\
\hline 122 & 32886.497 & 383066.804 & 2.7 & 4 \\
\hline 123 & 32870.771 & 383073.178 & 3.0 & 4 \\
\hline 124 & 32917.531 & 383077.663 & 2.4 & 2 \\
\hline
\end{tabular}




\begin{tabular}{||c|c|c|c|c||}
\hline \hline & Northing & Easting & Depth $(\mathrm{m})$ & $\begin{array}{c}\text { Dominant Substrate } \\
\text { Category }\end{array}$ \\
\hline \hline 125 & 32947.241 & 383058.211 & 1.5 & 3 \\
\hline 128 & 32881.100 & 383152.893 & 3.4 & 4 \\
\hline 129 & 32934.413 & 383115.330 & 3.0 & 3 \\
\hline 130 & 32917.122 & 383187.163 & 4.0 & 3 \\
\hline 131 & 32924.216 & 383183.539 & 3.4 & 3 \\
\hline 132 & 32952.790 & 383191.633 & 2.7 & 3 \\
\hline 133 & 32986.860 & 383202.229 & 2.7 & 3 \\
\hline 134 & 32992.716 & 383236.663 & 2.1 & 3 \\
\hline 135 & 32953.282 & 383279.514 & 4.6 & 3 \\
\hline 136 & 33577.610 & 382791.768 & 1.2 & $\mathrm{n} / \mathrm{a}$ \\
\hline 137 & 33574.700 & 382795.460 & 1.2 & 2 \\
\hline 138 & 33583.114 & 382804.403 & 1.2 & 2 \\
\hline 139 & 33583.635 & 382829.094 & 1.1 & 3 \\
\hline 140 & 33583.887 & 382847.477 & 0.9 & $\mathrm{n} / \mathrm{a}$ \\
\hline 141 & 33593.756 & 382837.295 & 1.1 & $\mathrm{n} / \mathrm{a}$ \\
\hline 142 & 33589.798 & 382830.711 & 0.9 & 2 \\
\hline \hline
\end{tabular}

